O. R. Strilets ${ }^{1}$, Cand. Sc. (Tech.), Assoc. Prof., orcid.org/0000-0003-3834-7176, V. O. Malashchenko ${ }^{2}$, Dr. Sc. (Tech.), Prof., orcid.org/0000-0001-7889-7303,

V. M. Strilets ${ }^{1}$, Cand. Sc. (Tech.), Assoc. Prof., orcid.org/0000-0003-2098-2315

\title{
ENERGY EFFECTIVENESS OF THE DIFFERENTIAL OF A DEVICE FOR SPEED CHANGE THROUGH THE SUN GEAR
}

Purpose. Theoretical and computer research and determination of performance efficiency of three- and four-stage gear differentials in speed changing devices through sun gears. Substantiation of the possibility of their use in machine drives based on estimating their energy efficiency and possible self-braking.

Methodology. To solve this problem, we used the method of "potential power"; by computer simulation, analytical expressions for the performance efficiency are obtained; using the MS Excel software package, the graphical dependencies of energy efficiency on the gear ratio, the angular velocity of the sun gear and the number of stages are obtained.

Findings. The obtained graphic dependences for the performance efficiency of three- and four-stage gears differentials allow one to follow visually the change in the value of the efficiency, depending on the angular velocity of the sun gear, the gear ratio and the number of steps. This allows us to estimate the perfection of the given differentials in terms of energy consumption and possible self-braking.

Originality. For the first time, analytical expressions were obtained for a more precise determination of the efficiency of a threeand four-stage differential gears with a driving carrier and a driven ring gear, or vice versa. Obtained from the analytical formulas, graphic dependences for the performance efficiency allow one to follow the change in the value of the performance efficiency.

Practical value. It is recommended for implementation in designing and constructing practice when developing the speed change devices through the differential transmissions of drives of various machines. It can be used in the educational process of technical higher educational establishments in mechanical engineering disciplines in the study of machines drives.

Keywords: energy efficiency, coefficient of performance efficiency, gear differential, sun gear, ring gear, epicycle, carrier and differential pinion

Introduction. Improving the energy efficiency of machinery is an important issue. Modern machines widely use devices in the form of stepped and stepless speed boxes, which, however, have many known shortcomings. The stepped speed boxes are constructively complex and possess a high material density, dynamic loads that arise when switching speeds. In steppless speed boxes, the intensive part wear due to the use of friction brakes is a great matter of concern. Abovementioned leads to a reduction in the durability and reliability of the parts of the machine drive and sets the task of creating new speed change devices that will improve drive's efficiency.

Development at the level of inventions (Patent No. 2211796 RU and Patent No. 44135 UA) of a cargo stop-gear and its application in differential gear transmissions, which are the subject of special interest, led to the creation of new devices for speed changes management at the level of patents of Ukraine, for example, No. 25335, No. 28489 and others. New devices created by the authors of this article eliminate existing shortcomings and improve efficiency of machines.

For their practical application, it is not enough to conduct power research or design. The knowledge about energy efficiency is required, which is proposed to evaluate by the performance efficiency (PE). Therefore, the determination of the PE for the differential gear transmissions, where speed control is carried out with the help of a closed cirquit hydrosystem through the sun gears is an urgent task partialy solved in [1] and [2].

In [1], a theoretical study have been carried out and the analytical expressions for the PE were derived for a singlestage differential gear transmission, when the driving link is a carrier, and the driven one is the ring gear or vice versa, the control link is the sun gear. With the help of computer simulation, the graphical dependences of PE on transmission parameters have been obtained.

In [2], analytical expressions and graphic dependences have been obtained to determine the efficiency of the two-

(C) Strilets O. R., Malashchenko V. O., Strilets V. M., 2019 stage differential transmission, which allow analyzing energy cost and self-braking in such transmissions.

This research for the first time solves the task of the theoretical and computer research on the energy efficiency of three- and four-stage differential gear transmissions, in order to draw conclusions about the possibility of their application in engineering.

Literature review. Differential gear transmission transitions are the subject of works [3-17].

In [3], the design of a bi-planetary transmission is presented with the calculations of the kinematics, statics and efficiency of gearing. Omitted from the calculation are the geometry and strength of gears, shafts and rolling bearings, as these are recognized as being typical design calculations.

In [4], on the basis of the torque, power balance equations and force analysis of the basic members, the power distributions of a $2 \mathrm{~K}-\mathrm{H}$ multistage micro-planetary gear reducer are analyzed.

In [5], the authors suggest an algorithm to resolve the problem of degenerate planetary gear train detection, automated by an interactive computer program. The algorithm is applicable for transmissions with any number of degrees of freedom.

In [6], a new method is proposed to calculate gear kinematic and power parameters based on hypergraph and matrix operation. PE computation is carried out by following the power flow, and power loss equations on each node are derived via an approach based on self-rotation relative power.

In [7], a joint analysis was held of the efficiency ranges and the transmission coefficient of planetary transmissions, which can be achieved by any possible constructive solutions.

In [8], the results were given of dynamical model verifying for the drive with a gearbox that was conducted on a real object in different operating conditions and stimulation studies to determine the suitability of the model, but without taking into account the energy efficiency.

In [9], the theoretical effectiveness formulas for the twostage differential gear transmission were obtained and verified by experimental studies. 
In [10], the performance eficiency of complex gear transmissions is investigated on the basis of graphic and screw theories, which allow obtaining approximate values.

In [11], the reduction in the construction cost of many high-speed planetary gear trains based on system synthesis is justified taking into account such requirements as the gear ratio, performance efficiency, planarity of the mechanism and one shifting, for heavy goods vehicles.

In [12], attention is drawn to the full understanding of the basic mechanics of planetary transmissions and the evaluation of their mechanical efficiency, and it is concluded that for the same input and output unit power loss has a peculiar mathematical expression for each actual sequence of angular velocities.

In [13] the reasons that hinder the application of smoothly controlled planetary transmission, due to the structural complexity of ratio control device and variants to simplify it are described.

In [14], attention was drawn to the fact that planetary transmissions are used in the industry for many benefits, which include high torque, increased efficiency and a very compact drive, and as made of gears - the failure of one link affects the whole transmission, so you need to know the reasons.

In [15], the average performance of an internal combustion engine is evaluated on models with a stepped and stepless gearbox and, in particular, the article indicates that the architecture with transmissions based on the planetary train sets allows the engine to operate in optimal conditions.

In [16], a composite power loss model in geared transmissions was developed and a study of the influence of the design parameters of planetary gear trains, bearings and lubrication properties on productivity was carried out.

In [17], the authors research the process of controlling speed changes by means of multistage differential gear transmission, when the driving link is a carrier, and the driven one is the ring gear or vice versa. The control link is the sun gear.

On the basis of the analysis of periodical scientific sources, it was concluded that little attention is given to the energy effectiveness of the multistage differential gear transmissions of the speed change devices through the sun gear. Therefore, the task of this work is the research on the energy effectiveness of three- and four-stage transmissions by the determination of the PE for their full evaluation from the point of view of energy losses and the possibility of self-braking depending on transmission parameters and the number of stages.

Purpose. The purpose of the work is to conduct the research on energy effectiveness of three- and four-stage differential gear transmissions in devices for speed change through a sun gear.

To achieve the aim, the following tasks were set:

- to obtain analytical expressions for PE determination;

- to get graphic dependences of PE on the angular velocity of the sun gear, ratio and number of stages;
- to draw conclusions about the energy effectiveness of such transmissions and the possibilities of self-braking and their application in technology.

Methods. The PE for planetary gear transmissions, whose components are differential gear transmissions, is traditionally determined based on frictional losses in each pair of gear wheels. These losses are proportional to the product of the circular force on the teeth and the velocity of the point on the initial circle of the planet in relation to the carrier, or the product of the torque of this force and an angular velocity. This product is called potential power and is used in determining the PE of a single-stage differential gear transmission, when the driving link is the carrier, and the the ring gear is driven, or vice versa [1]. Based on the technique [2] and results obtained in [17], the theoretical expressions for the PE of the three- and four-stage differential gear transmissions of the speed change device through sun gears are obtained in this article, and with the help of a computer simulation - graphical dependences on the gear ratio, control speed and the number of stages.

The results of studies on energy effectiveness of multistage differential gear transmission of a device for speed change through the sun gears. Considering the complexity of the problem, we have performed theoretical and computer determinations of the PE of multi-stage differential gear transmissions in speed changing devices with closed circuit hydrosystems on examples of three- and four-stage transmissions.

Fig. 1 shows a three-stage differential gear transmission, in which the ring gear $3_{(1)}$ of the first stage is connected with the carrier $4_{(2)}$ of the second stage, the ring gear $3_{(2)}$ of the second stage is connected with the carrier $4_{(3)}$ of the third stage.

Speed control is carried out due to sun gears of the first $1_{(1)}$, the second $1_{(2)}$ and the third $1_{(3)}$ stages with the help of closed circuit hydrosystems $6_{(1)}, 6_{(2)}$. and $6_{(3)}$ through gears $7_{(1)}, 7_{(2)}$. and $7_{(3)}$. The driving link of the three-stage differential gear transmission is the first-stage carrier $4_{(1)}$, and the driven link is the ring gear $3_{(3)}$ of the third stage. form

The expression for the PE of such transmission has the

$$
\eta_{4(1)-3(3)}=\eta_{43(1)} \eta_{43(2)} \eta_{43(3)},
$$

where $\eta_{43(1)}, \eta_{43(2)}, \eta_{43(3)}$ are PEs of, respectively, the first, second and third stages.

The PE of individual stage is determined, as shown in [2] by expression (2), and taking into account the connection between the angular velocities of the driving and the driven links of the adjusted stages and bringing them to the driving link - a carrier of the first stage, as described in [17], formula (10), we obtain an expression for determining the PE for a three-stage differential gear transmission in the device for speed change through the sun gears with driving carrier and driven ring gear.

$$
\begin{gathered}
\eta_{4(1)-3(3)}=\frac{\left[\left(1+u_{13(1)}^{(4)}\right) \omega_{4(1)}-\omega_{1(1)}\right] \eta_{13(1)}^{(4)} \frac{\left\{\left(1+u_{13(2)}^{(4)}\right)\left[\omega_{4(1)}\left(1+u_{13(1)}^{(4)}\right)-\omega_{1(1)}\right]-\omega_{1(2)} u_{13(1)}^{(4)}\right\} \eta_{13(2)}^{(4)}}{\left(1+u_{13(1)}^{(4)} \eta_{13(1)}^{(4)}\right) \omega_{4(1)}-\omega_{1(1)}} \times}{\left(1+u_{13(2)}^{(4)} \eta_{13(2)}^{(4)}\right)\left[\omega_{4(1)}\left(1+u_{13(1)}^{(4)}\right)-\omega_{1(1)}\right]-\omega_{1(2)} u_{13(1)}^{(4)}} \times \\
\times \frac{\left\{\left(1+u_{13(3)}^{(4)}\right)\left\{\left[\omega_{4(1)}\left(1+u_{13(1)}^{(4)}\right)-\omega_{1(1)}\right]\left(1+u_{13(2)}^{(4)}\right)-\omega_{1(2)} u_{13(1)}^{(4)}\right\}-\omega_{1(3)} u_{13(1)}^{(4)} u_{13(2)}^{(4)}\right\} \eta_{13(3)}^{(4)}}{\left(1+u_{13(3)}^{(4)} \eta_{13(3)}^{(4)}\right)\left\{\left[\omega_{4(1)}\left(1+u_{13(1)}^{(4)}\right)-\omega_{1(1)}\right]\left(1+u_{13(2)}^{(4)}\right)-\omega_{1(2)} u_{13(1)}^{(4)}\right\}-\omega_{1(3)} u_{13(1)}^{(4)} u_{13(2)}^{(4)}}
\end{gathered}
$$

Forthermore, for the quantitative analysis of the PE change, the expression (2) is programmed on the computer for the following parameters: the angular velocity of the driving link, the carrier, $\omega_{4(1)}=75 ; 100 ; 150 ; 300 \mathrm{rad} / \mathrm{s}$; angular velocities of control sun gears, $\omega_{1(1)}=\omega_{1(2)}=\omega_{1(3)}=0 \ldots 50 \mathrm{rad} / \mathrm{s}$; fixed carrier ratio of different stages taken $u_{13(1)}^{(4)}=u_{13(2)}^{(4)}=u_{13(3)}^{(4)}=1,0 \ldots 10$; PEs of transmission with fixed carrier ratio $\eta_{13(1)}^{(4)}=\eta_{13(2)}^{(4)}=\eta_{13(3)}^{(4)}=0.97$.

Graphic dependencies for these data have been obtained. One of them, for the case of $\omega_{4(1)}=100 \mathrm{rad} / \mathrm{s}$ is shown in Fig. 2.

A remark should be made here that to get general conclusions, we will construct the next graphic dependencies, taking the same initial data for other schemes of three- and four-stage differential gears.

Let us consider the three-stage differential gear transmission shown in Fig. 3, where the leading link is the ring gear $3_{(1)}$ of the first stage and the driven link is a carrier $4_{(3)}$ of the third stage.

The expression of the PE for this case will be

$$
\eta_{3(1)-4(3)}=\eta_{34(1)} \eta_{34(2)} \eta_{34(3)},
$$

where $\eta_{34(1)}, \eta_{34(2)}, \eta_{34(3)}$ are PEs of, respectively, the first, second and third stages.

The PE of an individual stage is determined, as shown in [2] by expression (4), and taking into account the connection between the angular velocities of the driving and the driven 
links, as described in [17], formula (11), we obtain an expression for determining the PE for a three-stage differential gear transmission in the device for speed change with driving ring gear and driven carrier.

$$
\begin{aligned}
& \eta_{3(1)-4(3)}=\frac{\left(\eta_{13(1)}^{(4)}+u_{13(1)}^{(4)}\right)\left(\omega_{1(1)}+\omega_{3(1)} u_{13(1)}^{(4)}\right)}{\left(1+u_{13(1)}^{(4)}\right)\left(\omega_{1(1)} \eta_{13(1)}^{(4)}+\omega_{3(1)} u_{13(1)}^{(4)}\right)} \frac{\left(\eta_{13(2)}^{(4)}+u_{13(2)}^{(4)}\right)\left[\omega_{1(2)}\left(1+u_{13(1)}^{(4)}\right)+\left(\omega_{3(1)} u_{13(1)}^{(4)}+\omega_{1(1)}\right) u_{13(2)}^{(4)}\right]}{\left(1+u_{13(2)}^{(4)}\right)\left[\omega_{1(2)} \eta_{13(2)}^{(4)}\left(1+u_{13(1)}^{(4)}\right)+\left(\omega_{3(1)} u_{13(1)}^{(4)}+\omega_{1(1)}\right) u_{13(2)}^{(4)}\right]} \times \\
& \times \frac{\left(\eta_{13(3)}^{(4)}+u_{13(3)}^{(4)}\right)\left\{\omega_{1(3)}\left(1+u_{13(1)}^{(4)}\right)\left(1+u_{13(2)}^{(4)}\right)+\left[\left(\omega_{3(1)} u_{13(1)}^{(4)}+\omega_{1(1)}\right) u_{13(2)}^{(4)}+\omega_{1(2)}\right] u_{13(3)}^{(4)}\right\}}{\left(1+u_{13(3)}^{(4)}\right)\left\{\omega_{1(3)} \eta_{13(3)}^{(4)}\left(1+u_{13(1)}^{(4)}\right)\left(1+u_{13(2)}^{(4)}\right)+\left[\left(\omega_{3(1)} u_{13(1)}^{(4)}+\omega_{1(1)}\right) u_{13(2)}^{(4)}+\omega_{1(2)}\right] u_{13(3)}^{(4)}\right\}} .
\end{aligned}
$$

To evaluate the nature of PE change in the three-stage differential gear transmission from the ring gear to the carrier, the expression (4) is programmed on the PC for the parameters similar to expression (2) programming, except for now ring gear is driving: $\mathrm{w} 3(1)=75 ; 100 ; 150 ; 300 \mathrm{rad} / \mathrm{s}$.

For these data, graphical dependencies of PE are constructed, some of which are shown in Fig. 4.

Furthermore, in Fig. 5, the scheme of four-stage differential gear transmission is depicted, in which the ring gear $3_{(1)}$ is connected with the carrier $4_{(2)}$, the ring gear $3_{(2)}$ is connected with the carrier $4_{(3)}$ and the ring gear $3_{(3)}$ is connected with the carrier $4_{(4)}$. Speed control is carried out due to sun gears $1_{(1)}$, $1_{(2)}, 1_{(3)}$ and $1_{(4)}$ with the help of closed circuit hydrosystems $6_{(1)}, 6_{(2)}, 6_{(3)}$ and $6_{(4)}$.

The driving link of this four-stage differential gear transmission is the carrier $4_{(1)}$, and the driven is the ring gear $3_{(4)}$.
Closed circuit hydrosystems $6_{(1)}, 6_{(2)}, 6_{(3)}$ and $6_{(4)}$ have similar structure, set on frame 5 and connected to corresponding sun gears by gearings $7_{(1)}, 7_{(2)}, 7_{(3)}$ and $7_{(4)}$.

Here, when driving link is a carrier and the driven is ring gear, the PE $\eta_{4(1)-3(4)}$ of such transmission can be defined as follows

$$
\eta_{4(1)-3(4)}=h_{43(1)} \eta_{43(2)} \eta_{43(3)} \eta_{43(4)},
$$

where $\eta_{43(1)}, h_{43(2)}, \eta_{43(3)}$ and $\eta_{43(4)}$ are PEs of, respectively, the first, second, third and forrth stages.

To determine PE, we use expression (2) from [2] again, and the connection between the angular velocities of the driving and the driven links we take as in [17], formula (10). That way we obtain an expression for determining the PE for a fourstage differential gear transmission in the device for speed change with driving carrier and driven ring gear.

$$
\begin{gathered}
\eta_{4(1)-3(4)}=\frac{\left.\left[\left(1+u_{13(1)}^{(4)}\right) \omega_{4(1)}-\omega_{1(1)}\right]\right]_{13(1)}^{(4)} \frac{\left\{\left(1+u_{13(2)}^{(4)}\right)\left[\omega_{4(1)}\left(1+u_{13(1)}^{(4)}\right)-\omega_{1(1)}\right]-\omega_{1(2)} u_{13(1)}^{(4)}\right\} \eta_{13(2)}^{(4)}}{\left(1+u_{13(1)}^{(4)} \eta_{13(1)}^{(4)}\right) \omega_{4(1)}-\omega_{1(1)}} \times}{\left(1+u_{13(2)}^{(4)} \eta_{13(2)}^{(4)}\right)\left[\omega_{4(1)}\left(1+u_{13(1)}^{(4)}\right)-\omega_{1(1)}\right]-\omega_{1(2)} u_{13(1)}^{(4)}} \times \\
\times \frac{\left\{\left(1+u_{13(3)}^{(4)}\right)\left\{\left[\omega_{4(1)}\left(1+u_{13(1)}^{(4)}\right)-\omega_{1(1)}\right]\left(1+u_{13(2)}^{(4)}\right)-\omega_{1(2)} u_{13(1)}^{(4)}\right\}-\omega_{1(3)} u_{13(1)}^{(4)} u_{13(2)}^{(4)}\right\} \eta_{13(3)}^{(4)}}{\left(1+u_{13(3)}^{(4)} \eta_{13(3)}^{(4)}\right)\left\{\left[\omega_{4(1)}\left(1+u_{13(1)}^{(4)}\right)-\omega_{1(1)}\right]\left(1+u_{13(2)}^{(4)}\right)-\omega_{1(2)} u_{13(1)}^{(4)}\right\}-\omega_{1(3)} u_{13(1)}^{(4)} u_{13(2)}^{(4)}} \times \\
\times \frac{\left\{\left(1+u_{13(4)}^{(4)}\right)\left\{\left\{\left[\omega_{4(1)}\left(1+u_{13(1)}^{(4)}\right)-\omega_{1(1)}\right]\left(1+u_{13(2)}^{(4)}\right)-\omega_{1(2)} u_{13(1)}^{(4)}\right\}\left(1+u_{13(3)}^{(4)}\right)-\omega_{1(3)} u_{13(1)}^{(4)} u_{13(2)}^{(4)}-\omega_{1(4)} u_{13(1)}^{(4)} u_{13(2)}^{(4)} u_{13(3)}^{(4)}\right\} \eta_{13(4)}^{(4)}\right.}{\left(1+u_{13(4)}^{(4)} \eta_{13(4)}^{(4)}\right)\left\{\left[\omega_{4(1)}\left(1+u_{13(1)}^{(4)}\right)-\omega_{1(1)}\right]\left(1+u_{13(2)}^{(4)}\right)-\omega_{1(2)} u_{13(1)}^{(4)}\right\}\left(1+u_{13(3)}^{(4)}\right)-\omega_{1(3)} u_{13(1)}^{(4)} u_{13(2)}^{(4)}-\omega_{1(4)} u_{13(1)}^{(4)} u_{13(2)}^{(4)} u_{13(3)}^{(4)}} .
\end{gathered}
$$

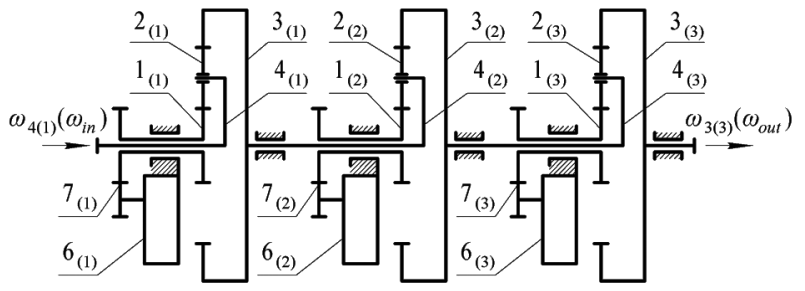

Fig. 1. Scheme of a three-stage differential gear transmission with driving carrier and driven ring gear [17]

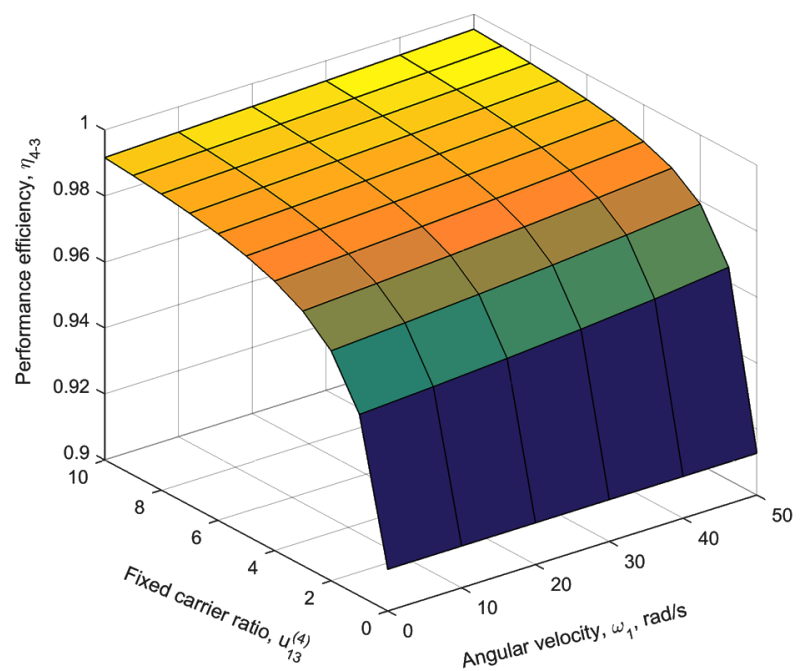

Fig. 2. Graphic dependencies for PE of the three-stage differential gear transmission with driving carrier and driven ring gear

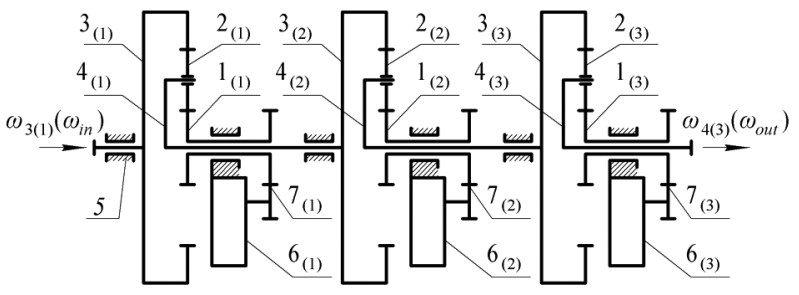

Fig. 3. The scheme of a three-stage differential gear transmission with driving ring gear and driven carrier

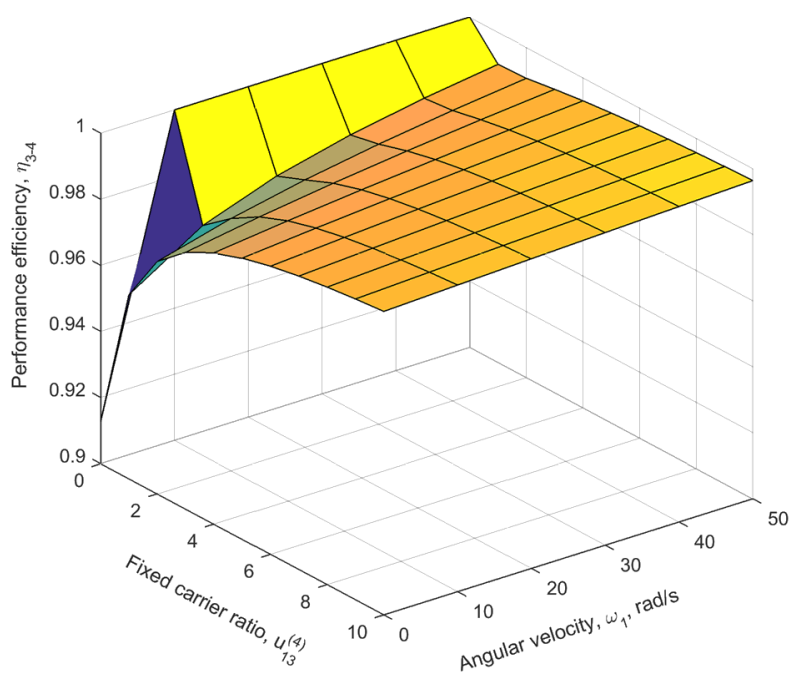

Fig. 4. Graphic dependencies for PE of the three-stage differential gear transmission with driving ring gear and driven carrier 


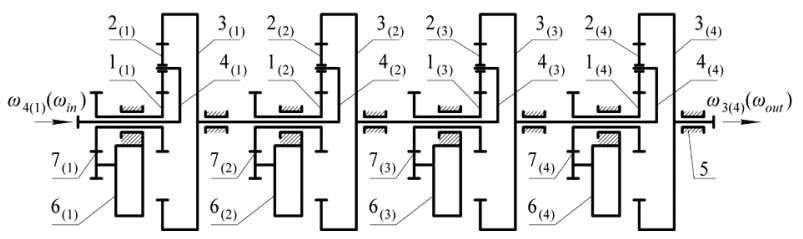

Fig. 5. Scheme of a four-stage differential gear transmission with driving carrier and driven ring gear

For the quantitative analysis of the PE change, the expression (6) is programmed on the PC for the parameters analogical to ones we take for three-srage differential gear transmission, extended fo the fourth stage.
Graphic dependencies of PE for these data and case of $\omega_{4(1)}=100 \mathrm{rad} / \mathrm{s}$ are shown in Fig. 6.

When the leading link of the four-step differential gear transmission is the ring gear $3_{(1)}$ of the first stage and the driven link is a carrier $4_{(3)}$ of the fourth stage (Fig. 7), the expression for the PE $\eta_{4(1)-3(4)}$ for this case will be

$$
\eta_{3(1)-4(4)}=\eta_{34(1)} \eta_{34(2)} \eta_{34(3)} \eta_{34(4)}
$$

where $\eta_{34(1)}, \eta_{34(2)}, \eta_{34(3)}, \eta_{34(4)}$ are PEs of, respectively, the first, second and third stages.

The PE of individual stages is determined, in the same way as for the three-stage differential gear transmission, and so we obtain an expression for determining the PE for a four-stage differential gear transmission in the device for speed change with driving ring gear and driven carrier.

$$
\begin{aligned}
\eta_{3(1)-4(4)}= & \frac{\left(\eta_{13(1)}^{(4)}+u_{13(1)}^{(4)}\right)\left(\omega_{1(1)}+\omega_{3(1)} u_{13(1)}^{(4)}\right)}{\left(1+u_{13(1)}^{(4)}\right)\left(\omega_{1(1)} \eta_{13(1)}^{(4)}+\omega_{3(1)} u_{13(1)}^{(4)}\right)} \times \frac{\left(\eta_{13(2)}^{(4)}+u_{13(2)}^{(4)}\right)\left[\omega_{1(2)}\left(1+u_{13(1)}^{(4)}\right)+\left(\omega_{3(1)} u_{13(1)}^{(4)}+\omega_{1(1)}\right) u_{13(2)}^{(4)}\right]}{\left(1+u_{13(2)}^{(4)}\right)\left[\omega_{1(2)}\left(1+u_{13(1)}^{(4)}\right) \eta_{13(2)}^{(4)}+\left(\omega_{3(1)} u_{13(1)}^{(4)}+\omega_{1(1)}\right) u_{13(2)}^{(4)}\right]} \times \\
\times \frac{\left.\left(\eta_{13(3)}^{(4)}+u_{13(3)}^{(4)}\right)\left\{\omega_{1(3)}\left(1+u_{13(1)}^{(4)}\right)\left(1+u_{13(2)}^{(4)}\right)+\left[\left(\omega_{3(1)} u_{13(1)}^{(4)}+\omega_{1(1)}\right) u_{13(2)}^{(4)}+\omega_{1(2)}\left(1+u_{13(1)}^{(4)}\right)\right]\right\} u_{13(3)}^{(4)}\right]}{(1+} \times & \left.\left.u_{13(3)}^{(4)}\right)\left\{\omega_{1(3)}\left(1+u_{13(1)}^{(4)}\right)\left(1+u_{13(2)}^{(4)}\right) \eta_{13(3)}^{(4)}+\left[\left(\omega_{3(1)} u_{13(1)}^{(4)}+\omega_{1(1)}\right) u_{13(2)}^{(4)}+\omega_{1(2)}\left(1+u_{13(1)}^{(4)}\right)\right]\right\} u_{13(3)}^{(4)}\right) \\
& \times \frac{\left(\begin{array}{l}
\left(\eta_{13(4)}^{(4)}+u_{13(4)}^{(4)}\right)\left\{\omega_{1(4)}\left(1+u_{13(1)}^{(4)}\right)\left(1+u_{13(2)}^{(4)}\right)\left(1+u_{13(3)}^{(4)}\right)+\left[\left(\omega_{3(1)} u_{13(1)}^{(4)}+\omega_{1(1)}\right) u_{13(2)}^{(4)}+\right.\right. \\
\left.\left.+\omega_{1(2)}\left(1+u_{13(2)}^{(4)}\right)\right] u_{13(3)}^{(4)}+\omega_{1(3)}\left(1+u_{13(1)}^{(4)}\right)\left(1+u_{13(2)}^{(4)}\right) u_{13(4)}^{(4)}\right\}
\end{array}\right)}{\left(\begin{array}{l}
\left(1+u_{13(4)}^{(4)}\right)\left\{\omega_{1(4)} \eta_{13(4)}^{(4)}\left(1+u_{13(1)}^{(4)}\right)\left(1+u_{13(2)}^{(4)}\right)\left(1+u_{13(3)}^{(4)}\right)+\left[\left(\omega_{3(1)} u_{13(1)}^{(4)}+\omega_{1(1)}\right) u_{13(2)}^{(4)}+\right.\right. \\
\left.\left.+\omega_{1(2)}\left(1+u_{13(2)}^{(4)}\right)\right] u_{13(3)}^{(4)}+\omega_{1(3)}\left(1+u_{13(1)}^{(4)}\right)\left(1+u_{13(2)}^{(4)}\right) u_{13(4)}^{(4)}\right\}
\end{array}\right.} .
\end{aligned}
$$

For greater visual perseption of the nature of PE change in the four-stage differential gear transmission from the ring gear to the carrier, the expression (8) is programmed on the PC for the parameters analogical to ones we take for three-srage differential gear transmission, extended fo the fourth stage.

For the data above, graphical dependencies of PE are constructed, some of which for $\omega_{3(1)}=100 \mathrm{rad} / \mathrm{s}$ are shown in Fig. 8 .

For the comparative estimation of the numerical values of the PEs of one-, two-, three- and four-stage differential gear

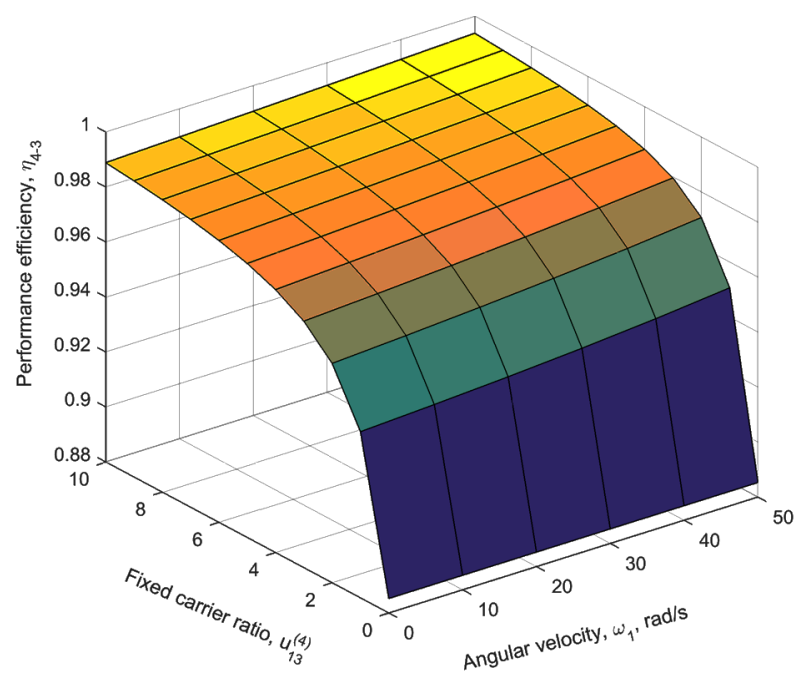

Fig. 6. Graphic dependencies for PE of the four-stage differential gear transmission with driving carrier and driven ring gear

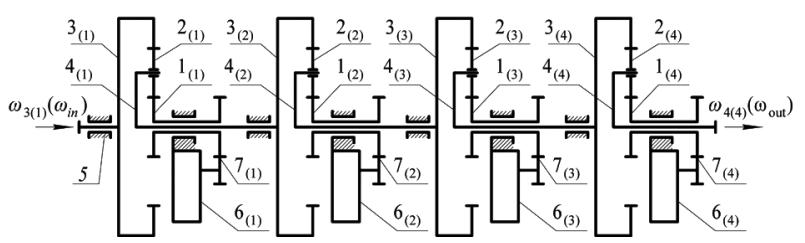

Fig. 7. The scheme of a four-stage differential gear transmission with driving ring gear and driven carrier transmission in the speed change devices, we use the results obtained in $[1,2]$ and this scientific work for the case when the carrier is driving, the ring gear is driven, and the control link is sun gear, and we construct graphic dependencies with the following data: angular velocities of the carriers $\omega_{4(1)}=75 ; 100$; $150 ; 300 \mathrm{rad} / \mathrm{s}$; angular velocities of control links - sun gears $\omega_{1(1)}=\omega_{1(2)}=\omega_{1(3)}=0 \ldots 50 \mathrm{rad} / \mathrm{s}$; gear ratios of individual stages are equal to $u_{13(1)}^{(4)}=u_{13(2)}^{(4)}=u_{13(3)}^{(4)}=1.0 \ldots 10$; and the PEs of transmission with fixed carrier ratio $\eta_{13(1)}^{(4)}=\eta_{13(2)}^{(4)}=\eta_{13(3)}^{(4)}=0.97$.

For example, Fig. 9 shows one of the following graphic dependencies for $\omega_{4(1)}=100 \mathrm{rad} / \mathrm{s}$ and $u_{13(1)}^{(4)}=u_{13(2)}^{(4)}=u_{13(3)}^{(4)}=3$.

Similarly, for the comparative estimation of numerical values of the PE of differential gear transmission with one, two, three and four stages in speed change devices when the ring gear is driving, carrier is driven, and the control link is the sun gear, we use the results obtained in $[1,2]$ and the given scientific work, and we get graphic dependencies for analogical to previous data cases. Graphic dependencies for $\omega_{3(1)}=100 \mathrm{rad} / \mathrm{s}$ and $u_{13(1)}^{(4)}=u_{13(2)}^{(4)}=u_{13(3)}^{(4)}=3$ are shown in Fig. 10.

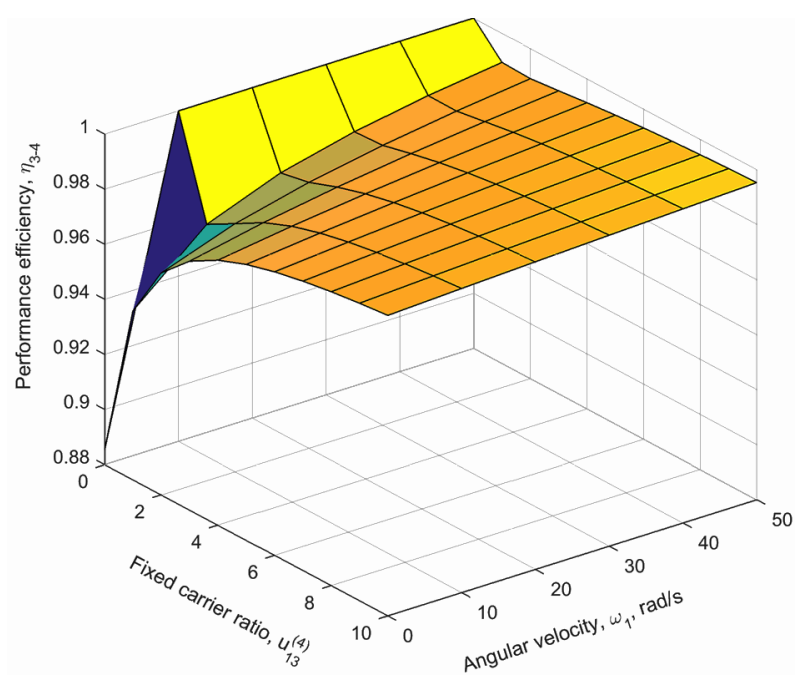

Fig. 8. Graphic dependencies for PE of the four-stage differential gear transmission with driving ring gear and driven carrier 


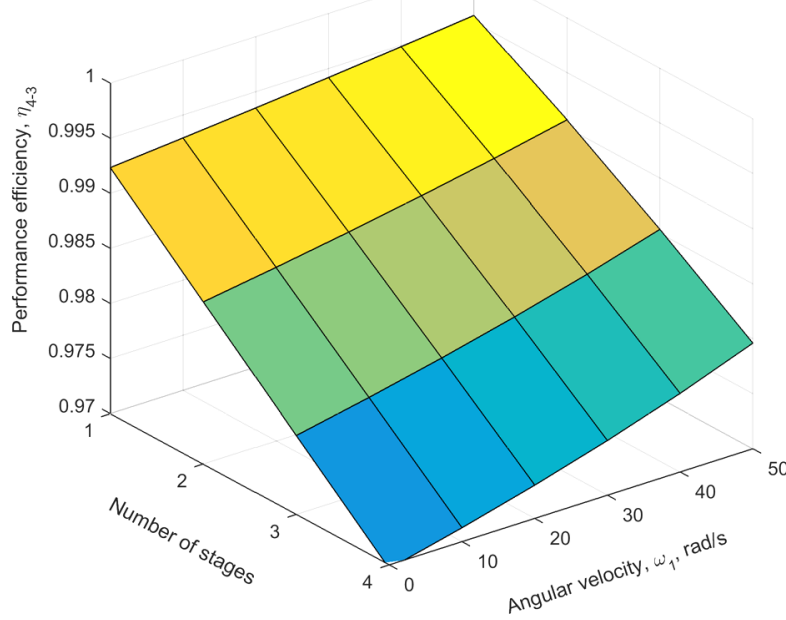

Fig. 9. Graphic dependencies of PE of the differential gear transmission with driving carrier and driven ring gear on the number of its stages

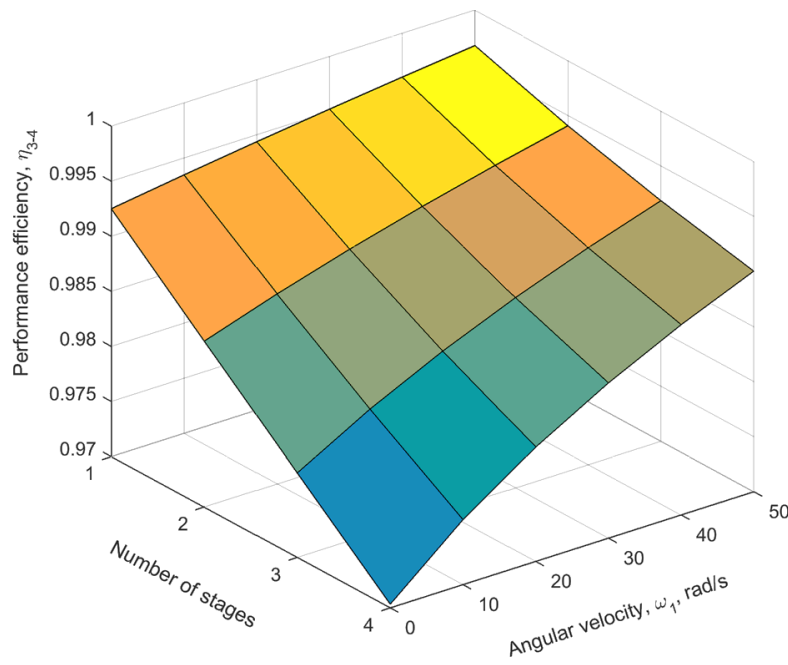

Fig. 10. Graphic dependencies of PE of the differential gear transmission with driving ring gear and driven carrier on the number of its stages

This method can evaluate the energy effectiveness of higher step number differential gear transmissions and draw conclusions about the possibility of their application in the machinery.

Conclusions.

1. For a three and four-stage differential gear transmission of a speed change device with a driving carrier and a driven ring gear, or vice versa, the analytical expressions of the determination of PE are obtained. The PE value can be used at the stage of development and design of such devices to assess their energy effectiveness.

2. The obtained graphic dependences for the performance efficiency of three- and four-stage differential gear transmissions can clearly trace the change in the PE, depending on the angular velocity of the sun gear, the gear ratio and the number of stages. This allows us to assess the perfection of a multistage differential gear transmission in terms of energy consumption and possible self-braking.

3. In all cases, the condition of self-braking is not possible for three- and four-stage differential gear transmissions, since the PE is far greater than zero. This proves the possibility and expediency of application in the technology of three- and three-stage differential gear transmissions.
4. Based on results of [1] and [2] and this research, we can conclude that with the increase in the number of stages of the differential gear transmissions, the performance efficiency decreases, which confirms the general laws.

\section{References.}

1. Strilets, O. R. (2017). The efficiency of the differential gear to devices for controlling the speed change through a sun gear. Odeskyi Politechnichnyi Universytet. Pratsi, 2(52), 29-38.

2. Strilets, O.R. (2017). Determination of the efficiency of multistage differential gear transmissions of speed change device via sun gear. Herald of National University of Water and Environmental Engineering. Technical Sciences, 1(77), 113123.

3. Drewniak, J., Garlicka, P., \& Kolber, A. (2016). Design for the bi-planetary gear train. Scientific Journal of Silesian University of Technology. Series Transport., 91, 5-17. https://doi. org/10.20858/sjsutst.2016.91.1.

4. Li Jianying, Hu Qingchun, Zong Changfu, \& Zhu Tianjun (2017). Power Analysis and Efficiency Calculation of Multistage Micro-planetary Transmission. Energy Procedia, 141, 654-659. https://doi.org/10.1016/j.egypro.2017.11.088.

5. Wenjian Yang, \& Huafeng Ding (2018). Automatic detection of degenerate planetary gear trains with different degree of freedoms. Applied Mathematical Modelling, 64, 320-332. https://doi.org/10.1016/j.apm.2018.07.038.

6. Fuchun Yang, Jianxiong Feng, \& Hongcai Zhang (2015). Power flow and efficiency analysis of multi-flow planetary gear trains. Mechanism and Machine Theory, 92, 86-99. https://doi. org/10.1016/i.mechmachtheory.2015.05.003.

7. Salgado, D. R., \& Castillo, J. M. (2014). Analysis of the transmission ratio and efficiency ranges of the four-, five-, and six-link planetary gear trains. Mechanism and Machine Theory, 73, 218-243, https://doi.org/10.1016/j.mechmachtheory.2013.11.001.

8. Grzegorz Peruń (2014). Verification of Gear Dynamic Model in Different Operating Conditions. Scientific Journal of Silesian University of Technology. Series Transport, 84, 99-104. 9. Pawar1, P. V., \& Kulkarni, P. R. (2015). Design of two stage planetary gear train for high reduction ratio. International Journal of Research in Engineering and Technology, 4(6), ESAT Publishing House, Bangalore, India, 150-157. https://doi. org/10.15623/ijret.2015.0406025.

10. Chao Chen, \& Jiabin Chen (2015). Efficiency analysis of two degrees of freedom epicyclic gear transmission and experimental. Mechanism and Machine Theory, 87, 115-130. https://doi.org/10.1016/i.mechmachtheory.2014.12.017.

11. Tianli Xie, Jibin Hu, Zengxiong Peng, \& Chunwang Liu (2015). Synthesis of seven-speed planetary gear trains for heavy-duty commercial vehicle. Mechanism and Machine Theory, 90, 230-239. https://doi.org/10.1016/j.mechmachtheory.2014.12.012.

12. Esmail, E. L., Pennestrì, E., \& Hussein, Juber A. (2018). Power losses in two-degrees-of-freedom planetary gear trains: A critical analysis of Radzimovsky's formulas. Mechanism and Machine Theory, 128, 191-204. https://doi.org/10.1016/j. mechmachtheory.2018.05.015.

13. Dankov, A. M. (2018). Planetary Continuously Adjustable Gear Train with Force Closure of Planet Gear and Central Gear: From Idea to Design. Science \& Technique, 17(3), 228237. https://doi.org/10.21122/2227-1031-2018-17-3-228-237.

14. Dobariya Mahesh (2018). Design of Compound Planetary Gear Train. International Journal for Research in Applied Science and Engineering Technology, 6(4), 3179-3184. https://doi. org/10.22214/ijraset.2018.4527.

15. Bonfiglio, A., Lanzarotto, D., Marchesoni, M., Passalacqua, M., Procopio, R., \& Repetto, M. (2017). Electrical-Loss Analysis of Power-Split Hybrid Electric Vehicles. Energies, 10(12), 21-42. https://doi.org/10.3390/en10122142.

16. Nutakor, C., Kłodowski, A., Sopanen, J., Mikkola, A., \& Pedrero, J. I. (2017). Planetary gear sets power loss modeling: 
Application to wind turbines. Tribology International, 105, 4254. https://doi.org/10.1016/j.triboint.2016.09.029.

17. Malashchenko, V. O., Strilets, O.R., \& Strilets, V.M. (2016). Speed changes management via multi-step differential gear transmission through the sun gear. Herald of National Technical University "Kharkiv Politehcnic". Problems of Mechanical Drive, 23(1195), 51-57.

\section{Енергетична ефективність диференціала пристрою зміни швидкості через сонячне зубчасте колесо}

\section{О. Р. Стрілецьь ${ }^{1}$, В. О. Малащенко ${ }^{2}$, В. М. Стрілець $^{1}$}

1 - Національний університет водного господарства та природокористування, м. Рівне, Україна, e-mail: o.r.strilets@nuwm.edu.ua

2 - Національний університет „Львівська політехніка“, м. Львів, Україна, e-mail: volod.malash@gmail.com

Мета. Теоретично-комп'ютерне дослідження й визначення ККД три- та чотириступінчастих зубчастих диференціалів у пристроях для керування змінами швидкості через сонячні колеса. Обгрунтування можливості використання їх у приводах машин на основі оцінки енергетичної ефективності та можливого самогальмування.

Методика. Для досягнення мети використаний метод „потенціальної потужності“, за допомогою комп’ютерного моделювання отримані аналітичні вирази для ККД, iз застосуванням програмного пакету MS Excel отримані графічні залежності енергетичної ефективності від передаточного відношення, кутової швидкості сонячного колеса та числа ступеней.

Результати. Отримані графічні залежності для ККД три- та чотириступінчастих зубчастих диференціалів наочно дозволяють прослідкувати зміну значення ККД у залежності від кутової швидкості сонячного колеса, передаточного числа та числа ступеней. Це дозволяє оцінити досконалість даних диференціалів з точки зору енерговтрат і можливого самогальмування.

Наукова новизна. Уперше отримані аналітичні вирази для більш точного визначення ККД три- та чотириступінчастих зубчастих диференціалів з ведучим водилом i веденим епіциклом, або навпаки. Отримані графічні залежності за допомогою аналітичних виразів дозволяють наочно прослідкувати зміну значення ККД.

Практична значимість. Рекомендується для впровадження у проектну й конструкторську практику при розроблені конструкцій пристроїв зміни швидкості через диференціальні передачі приводів різної техніки. Можливе застосування в навчальному процесі вищих технічних навчальних закладів у дисциплінах машинознавства при вивченні приводів машин.

Ключові слова: енергетична ефективність, коефіцієнт корисної діі, зубчастий диференціал, сонячне колесо, епіцикл, водило й сателіт диференціала

\section{Энергетическая эффективность дифференциала устройства изменения скорости посредством солнечного зуб̆чатого колеса}

\section{О. Р. Стрилеи ${ }^{1}$, В. О. Малащенко ${ }^{2}$, В. Н. Стрелеи, ${ }^{1}$}

1 - Национальный университет водного хозяйства и природопользования, г. Ровно, Украина, e-mail: o.r.strilets@nuwm.edu.ua

2 - Национальный университет „Львовская политехника“, г. Львов, Украина, e-mail: volod.malash@gmail.com

Цель. Теоретико-компьютерное исследование и определение КПД трех- и четырехступенчатых зубчатых дифференциалов в устройствах изменения скорости посредством солнечных колес. Обоснование возможности использования их в приводах машин на основании оценки энергетической эффективности и возможного самоторможения.

Методика. Для достижения цели использован метод „потенциальной мощности“, при помощи компьютерного моделирования получены аналитических выражений для КПД, с применением программного пакета MS Excel получены графические зависимости энергетической эффективности от передаточного отношения, угловой скорости солнечного зубчатого колеса и числа ступеней.

Результаты. Полученные графические зависимости для КПД трех- и четырехступенчатых дифференциалов наглядно позволяют проследить изменение значения КПД в зависимости от угловой скорости солнечного колеса, передаточного отношения и числа ступеней. Это позволяет оценить совершенство данных дифференциалов с точки зрения энергопотерь и возможного самоторможения.

Научная новизна. Впервые получены аналитические выражения для более точного определения КПД трех- и четырехступенчатых зубчатых дифференциалов с ведущим водилом и ведомым эпициклом, или наоборот. Полученные графические зависимости при помощи аналитических выражений позволяют наглядно проследить изменение КПД.

Практическая значимость. Рекомендуется для внедрения в проектную и конструкторскую практику при разработке конструкций устройств изменения скорости посредством дифференциальных передач приводов различной техники. Возможно применение в учебном процессе высших технических учебных заведений в дисциплинах машиноведения при изучении приводов машин.

Ключевые слова: энергетическая эффективность, коэффициент полезного действия, зубчатый дифференциал, солнечное колесо, эпицикл, водило и сателлит дифференциaла

Recommended for publication by I. V. Kuzio, Doctor of Technical Sciences. The manuscript was submitted 19.02.19. 